Modern Asian Studies 34, 2 (2000), pp. 425-447. (C) 2000 Cambridge University Press Printed in the United Kingdom

\title{
A Hindi Poet from Allahabad: Translating Harivansh Rai Bachchan's Autobiography
}

\author{
RUPERT SNELL \\ School of Oriental and African Studies, University of London
}

The poet known to the Hindi literary world as 'Bachchan' was born as 'Harivansh Rai' in 1907 to an Allahabad Kāyasth family. His given name derived from a prescribed recitation of the Harivamśa Purāna that had broken his parents' much-lamented childlessness; the pandit's honorarium for the recitation was 1001 rupees, paid off in monthly instalments over the first ten years of the boy's childhood. The roman spelling of the name varies, the Sanskritic 'Harivansh' standing in contrast to the form 'Harbans' with which the author's Ph.D. thesis is signed. Such a distinction is not without significance, for underlying the author's cosmopolitan exterior lies an intimately provincial Allahabadi character more fully caught by the 'Harbans' spelling than its somehow sanitized, all-India tatsama equivalent. It is a feature that one longs in vain to recapture in English translation many a time, for example to resonate with the semi-tatsama phrase pürab-pacchim, for 'East and West', so much more redolent of the vernacular scene than its Sanskritic parent pūrva-paścim. But in English, East is 'East' and West is 'West'.

While known primarily for his poetry, Harivansh Rai Bachchan also attracted much critical attention with the publication of his autobiography, the first volume of which appeared in 1969. The narrative starts several generations before the birth of the author, and one of its many pleasures is the way the soft focus of legend crispens into the tighter narrative of remembered and contemporary relatives. Halfway between the legendary and the observed stands Bachchan's great-grandfather Mitthulal, brother to the younger Radha, whom he rescued from unsympathetic in-laws:

He was a six-footer with a body of steel, much given to physical exercise and expert with both lathi and blade-he kept a whole collection of swords and daggers. He was a good horseman, and he kept falcons too. He was a very hot-tempered man, and there were those outside the family who would call him despotic and cruel. It was said that lamps would burn with his urine and that stems of grass would stand erect at his command. But with oo26-749X/oo/ $\$ 7.5^{\mathrm{O}+\$ 0.10}$ 
his sister he was tenderness itself; he would seat her next to him and feed her, and would call her 'Radhe' very sweetly. When he got angry Radha was the only one who dared appease him.

Radha's arrival in the household proved a good omen for Mitthulal, for shortly afterwards he was put in charge of the town's police by the Company government; in my childhood all the local notables remembered him as 'Nayab Sahib'. Police service was ideally suited to his temperament. In those days when people were generally unaware of the law and their rights, many matters must have been despatched by main force, and his overbearing form and terrifying aspect certainly ensured the Nayab Sahib's success as an officer. Radha told me countless tales of his victorious encounters with thieves, dacoits and villains, and indeed she herself derived some strength from her brother's position. All her fear of her in-laws evaporated. They never attempted to call her back, but rather would send gifts of mangoes, jackfruit, maize, ears of millet, or peas in the pod, according to season; and no matter what weddings or funerals took place in that household, no matter what news or invitations came from those in-laws, Radha stuck to her resolve never to darken their door again.

The Nayab Sahib made a lot of money and built a great house which Radha called 'the fort'. But not being a hoarder, he spent his cash as fast as he earned it. He was a man inclined to strong passions, perhaps even addicted to them, and his virility accounted for the occupancy of two or three 'houses' in the city - a fact whose significance I only learned when I grew older. But in those days such addictions were considered nothing more than a natural symptom of wealth. The Nayab Sahib was a hedonist, freely open-handed in all matters of food and drink. He celebrated his son's marriage in Mirzapur with great pomp, and his daughter's in Akohria village in Rae Bareli. By contrast his wife was miserly, and used to lament and wrangle at the Nawab's spendthrift ways, but to no effect. It was said that she had buried a potful of gold coins somewhere within that great rambling house, without telling anyone; she died unexpectedly, and over the next three generations the family would periodically excavate in search of that crock of gold, now here, now there, now in several places at once, but it was never found. The last time such a search was carried out was at my father's initiative on the occasion of my sister's wedding, under a veil of secrecy ... but again the attempt was fruitless. ${ }^{1}$

Harivansh Rai's grandfather had been a jail superintendent in Lalitpur, his father a clerk in the Pioneer-the newspaper which had once included the young Rudyard Kipling amongst its editorial staff. His autobiography tells of a close personal friendship with a boyhood neighbour, Karkal, and of Karkal's untimely death after contracting a fever; we also learn of Bachchan's intimate connection with Karkal's widow Champa. This relationship is adumbrated by the following

\footnotetext{
${ }^{1}$ Quotations from the translated text are from Harivansh Rai Bachchan, In the Afternoon of Time: an Autobiography, trans. Rupert Snell (Delhi, Penguin Books, 1998).
} 
paragraph, which is typical of the more lyrical passages in the book, not least in respect of its allusions to English literature:

Champa was a fair, willowy girl, her body slender like a golden cane; her face had no easy-going cheerfulness, none of the flightiness that is admired in girls of her age, but a languorous look-perhaps born of the repressive control of her foster-mother-which seemed to crave sympathy while also being keen to bestow it on others. Yet perhaps the circumstances in which I first set eyes on Champa concealed her true form, which I was to see two or three months later when she was sitting on the low parapet of the roof terrace overlooking Mohan Chacha's house, wearing a light blue sari, free of jewellery or adornments. Immediately below in Mohan Chacha's courtyard there stood a lasora tree whose upper branches overspread the roof where she sat, and whose half-open foliage seemed to imitate her own incipient beauty. At that time I lacked the words to describe it: only years later did they come to me, borrowed from Keats' Ode to a Nightingale'light-winged Dryad of the trees'; light-winged she was, and doubtless that is why she was to fly from us in the blinking of an eye, disappearing into the limitless heavens.

The intimate description of Bachchan's relationship first with Karkal and then with Champa is remarkable for its candour; while leaving much to be read between the lines, the account of the friendship with Karkal has led the Hindi critic Namvar Singh ${ }^{2}$ to reckon it the first published confession in Hindi of a homosexual relationship. Harivansh Rai's subsequent marriage to Shyama ended tragically with her illness and death, an event which cast a long and dark shadow over the young poet. He used his family endearment of 'Bachchan', 'little one' (deriving from baccā 'child'), to sign his lyric poems, noting that 'I accepted the pet name my parents called me by as a child, and used it for my writing career, despite the fact that a terse, unimpressive and domestic name such as "Bachchan" had little resemblance to the literary and mellifluous-sounding appellations that writers generally aspired to in those days.' After trying his hand at a number of jobs, Bachchan took to schoolmastering, and eventually secured the prize of a lectureship in English at Allahabad University (then the pride of northern India's academic establishment), where he was to work alongside Raghupati Sahay 'Firaq' and Amarnath Jha. Other formative experiences included close contact with the sharper end of the independence movement, specifically those figures surrounding the writer and revolutionary Yashpal. Bachchan's engagement here was more personal than polit-

\footnotetext{
${ }^{2}$ In a personal communication.
} 
ical; and the veracity of his account has been hotly and derisively questioned by Yashpal's widow Prakashwati Pal (Bachchan's 'Prakasho' in her 1994 autobiography Lāhaur se Lakhnaū tak.

Falling under the spell of Fitzgerald's Omar Khayyam, Bachchan translated it into Hindi, and in the same year, 1935, wrote his own poem Madhuśālā, 'The House of Wine', ${ }^{3}$ the work which established his reputation as a poet whose impassioned kavi sammelan recitals attracted massive crowds. In the early $195^{\circ}$ os a combination of circumstances took Bachchan to Cambridge where he wrote a Ph.D. thesis on Yeats under T.R. Henn in St Catherine's. (Bachchan is often described as the first Indian to take a Ph.D. in English at Cambridge, but reckons himself the third.) His research included a spell in Ireland, working on original Yeats documents with the encouragement of Yeats' widow. Back in Allahabad in the early fifties, Bachchan found himself cold-shouldered by his jealous university colleagues, and eventually found a new career as 'Officer on Special Duty-Hindi' in the foreign ministry of his fellow-Allahabadi Jawaharlal Nehru, Prime Minister of the newly independent India. By this time Bachchan, after some inconclusive (if formative) romantic attachments, had married Teji Suri, a Panjabi girl from a Sikh family, and together they made the move from the family home in Allahabad to the capital, accompanied by their two young sons Amitabh and Ajitabh. The old links with Allahabad were never broken, but the subsequent decades were spent mostly in Delhi or Bombay, with the magnetism of the latter growing inexorably with Amitabh's meteoric success in films. Bachchan's poetry-writing continued throughout a succession of government assignments, which included a term as a member of the Rajya Sabha and several foreign tours. Dr Bachchan and his wife Teji now live in Bombay, sheltered in old age by their family.

The literary status of Bachchan today is ambiguous. His Khayyaminspired Madhuśálā is still a popular work, much anthologized, perennially in print, and given a new lease of life by the recording of Manna De in which the poet himself recites the opening verse. Harish Trivedi observes:

\footnotetext{
${ }^{3}$ This English title was given to the work by its English translators Marjorie Boulton and Ram Swaroop Vyas; the English edition was published by the Fortune Press in 1950, and reappeared under the title Madhushala under the Penguin (India) imprint in 1989. The translation has a brief preface by Jawaharlal Nehru, who noted 'Bachchan is a well-known Hindi poet and I like this Madhushala of his'.
} 
it is the tension between orthodox Hindu religious piety and the rebellious and profane act of drinking which constitutes the keynote of the poem. Indeed, it was this mild blasphemy which gave the poem its ability to shock when it first appeared and ensured its succès de scandale particularly among the Hindi-Hindu readers by whom the Persian-Muslim joys of imbibing were seen as deliciously wicked. ${ }^{4}$

Though Bachchan later moved on to a broader poetic canvas, this early success was to define him forever as the poet, not to say the (teetotal) publican, of the House of Wine; and India's fondness for taxonomy soon dubbed his style 'Hālāvād' after the word $h \bar{a} l \bar{a}$ (a Sanskritic word for 'wine', but also neatly congruent with the Persianderived $h \bar{a} l$, with its Sufi implication of 'ecstatic frenzy' and the Arabic hāla, '(lunar) halo') which provides one of the running rhymes for the eponymous madhuśāla . A tempting translation for hāalaveadd, though admittedly working better on the silent page than when vocalized, might be 'Bachchanalia'.

Like its Victorian model, Madhuśălā has acquired a kind of Golden Treasury immortality even if only rarely accorded the dignity of academic study; and when the name of Bachchan the poet comes up in conversation, this is the work which springs most readily to people's minds. But the world has moved on, and that sweet preindependence lyricism is severely out of fashion in today's literary circles. Bachchan's poetry lacks the incisive irony of more contemporary verse, nor can it claim the automatic security of 'classic' works from earlier periods. His position lies in the grey area between the intellectual rigorousness of Eliot-and-Pound groves on the one hand, and the newly-sanctified arcadia of popular culture on the other. Thus Bachchan has committed one of the worst crimes of the modern literary context: he is middle-brow. Scathing in his own writings of the popularizing antics of the contemporary kavi-sammelan or verse recital, which he regards as artistically bankrupt, Bachchan himself rode to fame on just this public vehicle, or a less decadent version of it; and the wildly enthusiastic public response that his recitations won over many years is itself an extraordinary phenomenon that deserves serious critical attention while the memories of those live audiences are still available for research.

Bachchan's total output of prose and poetry is not exhausted by the nine substantial volumes that make up his Racanāvalī or 'col-

\footnotetext{
${ }^{4}$ Harish Trivedi, Colonial Transactions: English Literature and India (Manchester, 1995), p. 40.
} 
lected works'. ${ }^{5}$ His corpus includes many collections of poetry, some Shakespeare translations (Hamlet, King Lear, Macbeth), reminiscences, a diary of his Cambridge years, and our four volumes of autobiography. The four volumes all have allusive titles. The first, Kyā

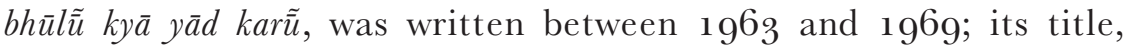
'What should I remember, what should I forget?' is taken from a poem written some years earlier. ${ }^{6}$ The second, Nìr $k \bar{a}$ nirmān phir, was written between 1963 and 1970 , and its 'rebuilding the nest' reference, deriving from Shelley's 'When hearts have once mingled/ love first leaves the well-built nest' alludes to Bachchan's coming to terms with his first wife's death, and his remarriage. Basere se dür or 'Far from home' was written in 1971-72 and 76-77, and includes a long section describing Bachchan's sojourn in Cambridge and Ireland. It was intended to be the last volume of the autobiography, and ends in valedictory mode as follows:

And so, reader (forgive me for addressing you like Montaigne), ${ }^{7}$ my book is a great lie in the face of life and I see no reason why you should be seduced by my pretty words into expending any more valuable time on such worthless and purposeless pastimes. Thus on the seventh day of the seventh month of 1977 , Bachchan takes his leave.

The title of the fourth and positively final volume, Daśdvār se Sopān tak, alludes to the two houses which frame this part of the narrative: 'Dashdwar', the house in Clive Road, Allahabad, where the Bachchans lived after his return from Cambridge, and 'Sopaan' ('the stairway', the title of a 1953 poetry collection), the house that Bachchan built in the writers' colony of Gulmohur Park in Delhi after his move to the capital. ${ }^{9}$ By 1991 when the fourth volume was published, the earlier three had been through ten, seven and five editions respectively.

${ }^{5}$ Published by Rājkamal, Delhi: various editions.

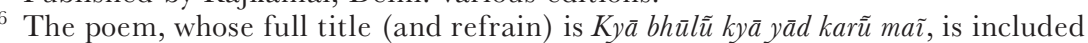
in Baccan Racanāvalī vol. 1 (3rd edn, Delhi, Rājkamal, 1987), p. 197.

7 Montaigne's preface to his Essays was adopted by Bachchan as a preface for Kya bhūl $\tilde{u}$ kyā yād karũ.

${ }^{8}$ The house did apparently have the eponymous 'ten doors'; but the name also alludes to the human body (with its ten orifices) as symbolically envisioned in Hindu metaphysics.

${ }^{9}$ The allusive habit has been used in reverse, as it were, in the use of the title Basere se dūr as the name of a house belonging to the Bachchan family in Hampstead (its Nagari nameboard exotic amongst the Range Rovers); and in the name of the earliest known Bachchan ancestor, Mansa, as the name of a new Bachchan house in Bombay. 
In translating the autobiography, its great length and prolific detail had to be substantially reduced to appeal to an English readership; the task involved reducing four books of Hindi-some 1,200 pages - into a single volume of English. At that time I did not have the close contact with Dr Bachchan which would have allowed me to consult him about such a task; and the knowledge that a would-be editor had been denied permission to prepare an abridged edition of his Hindi text earned additional nervousness. However, re-reading the text suggested a set of priorities and conventions on which the abridgement-cum-translation might logically be based.

One had to take into account the fact that the autobiography was written over a period of some 22 years: from 1963 to 1985 . At the beginning of this period Dr Bachchan was a $5^{6 \text {-year-old government }}$ servant, working for Nehru in New Delhi; at the end of it, he was 78 and retired. Naturally this passage of years brought a changing perspective, and the last of the four volumes of autobiography is more detailed and perhaps more prolix than the first: although covering a rather shorter period than each of the earlier volumes, it is twice the length of any one of them. The narrative of the first volume is tightly written, with a fine eye for synecdochic description; its history of the author's family emerges beautifully from a retrospective gaze cast back into the mists of dynastic time, tracing the psychological stereotypes with which caste-based society has adorned or defaced the image of the Kāyasths over history. Examples of observed detail include an uncle's eye-witness account of the Jallianwala Bagh massacre, anguished tears flooding the smallpox scars on his cheek; or Bachchan's own childhood recollection of standing nervously in his headmaster's study, noticing how the framed wallmap of the United Provinces looked like a dog, wih Jhansi and Mirzapur districts as its legs and Dehra Dun as its head.

The United Provinces survived their transformation to Uttar Pradesh with initials intact, even though the mooted formation of the new state of Uttarakhand may now threaten Bachchan's dog with decapitation. But many features of U.P. society have changed radically during Bachchan's long life, and in abridging the autobiography a priority was to preserve as much of its historical depth of field as possible. This seemed best done by gradually increasing the textual deletions exponentially from volume to volume, preserving most of the earlier sections but only a much reduced proportion of the later. An advantage of this technique was that it brought a balanced time structure to the resulting single volume-such as might arguably 
have been aimed for by the author himself had he written a synoptic survey of his life at one sitting. There were some problems in the compression of the narrative; for example, innocent remarks made earlier in the story take on an ironic burden with later developments, as when an elderly uncle of the author's writes to him saying, 'I hear your boy Amitabh has become an actor' (it is rather as if someone wrote, 'Dear Nancy, I hear Ronald is going into politics'). But a narrative thread was maintained, the divisions of the four books being retained as separate sections in the translation, with the fourth and last - the afterthought—being labelled an 'epilogue'.

The second criterion for abridging the text was a more subjective assessment of its contents and of its likely English-language readership. As a writer whose predominant activity, character and psychology is that of a lyric poet, Bachchan necessarily devotes much space to the quotation and discussion of large amounts of verse-whether his own or that of others. In the Hindi original the poetry blends well in both context and register with the surrounding narrative, which picks up their points of reference and weaves the verses seamlessly into the whole. But translate the poetry into English and this delicate balance is immediately disturbed: the verses stand out awkwardly against the backdrop of the narrative, and the unfolding of the story seems arrested by the awkwardly self-conscious shift between prose and verse. Accordingly most of the poetry and its accompanying discussion was excised from the translation.

When the narrative itself depended on the existence of a verse passage, then of course it had to be retained. In one such passage, illustrative of contemporary mores and of the poetic world, Bachchan describes his defence of Madhuśälā when someone had complained to Mahatma Gandhi that the poem promoted the consumption of alcohol.

I have many memories of the [Indore] kavi sammelan, chaired, I fancy, by Mahadeviji, ${ }^{10}$ as in Delhi the year before. There was a whole group of poets from Kanpur who wrote kavitt verses; Navinji, though a Kanpuriya himself, kept aloof from them. Siyaram Sharan Gupta spun cotton while reciting, but forgot his lines, and his recitation disintegrated into a stammering confusion; the public is very unforgiving, and he had to leave the stage, deserted by his muse. His poetry was worthy but dry, like the cotton he worked so deftly in one hand. Pandit Anup Sharma 'Anup' seemed a clown in conversation, but became a lion when reciting kavitt, not speaking his lines but roaring them.

${ }^{10}$ Mahadevi Varma (1907?-1987), doyenne of the Chāyāvād school of Hindi poetry. A verse of hers is cited later in this paper. 
I recited Madhushala to the people of Indore for the first time. The audience was enraptured, though many perhaps did not understand what this 'house of wine' was all about. Somebody had complained to Gandhiji that the Conference he was chairing was glorifying the consumption of alcohol. I was summoned to see Gandhiji one night just before a midnight meeting of the executive committee. Even people anxious to meet Gandhiji were not getting appointments, so I felt both happy and a little apprehensive at being called; if he said that I should not recite Madhushala or should destroy it, how would I be able to refuse? Gandhiji mentioned the complaint and asked to hear a few verses. I adopted a certain caution in my choice of rubais, selecting those whose symbolic meaning would be readily accessible to him:

Now steps the drinker from his home,

The drinking house his eager aim;

'Which path to take?'- - poor simple soul,

He sees all paths look just the same.

The passers-by give this or that Advice, but hearken now to mine-

Take any road you like, my friend, You'll find for sure the House of Wine. ${ }^{11}$

O Muslim, Hindu-faiths are two,

But one the brimming cup you share;

And one the drinking house, and one

The wine which flows so freely there.

By mosque and temple all's divided,

All is either 'mine' or 'thine';

But feuds thus forged are all at last

Forgotten in the House of Wine. ${ }^{12}$

'There's no wine-glorifying in these verses!', said Gandhiji, and with this exoneration I hurriedly took my leave. He had his meeting to go to. This was the first and last occasion on which I sat in close proximity to Gandhiji.

Another example of a verse retained in the translation is from Bachchan's Allahabad schooldays, when the children were made to sing a four-line hymn extended by an additional line declaring fealty to the imperial throne. This particular passage turned out to be a translator's dream, because the quoted verse was followed by the

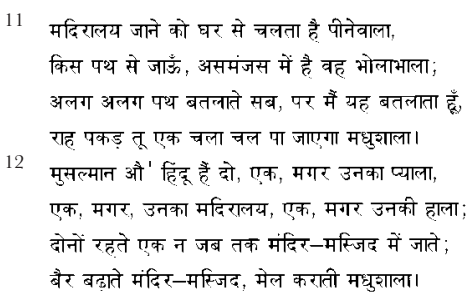


sentence 'The song had been composed by a person innocent of any knowledge of prosody, but nobody seemed to notice or care'. Here then was an invitation to write bad English poetry in the interests of faithfulness of translation.

Oh Lord, who yields all bliss and joy, pray grant us wisdom's gift; and all ignoble vices' burden from us swiftly lift;

Grant us refuge safe and sure, on virtue's path proceeding;

Faith-protecting, celibate, to strength and truth acceding.

Long life to George the Fifth, our king: God, kindly hear our drift. ${ }^{13}$

There was also fun to be had in dealing with some of Bachchan's childhood poetic pranks. His grandfather had copied out in manuscript the text of the verse dictionary Khäliqbāri (optimistically attributed to Amir Khusrau), and this was entrusted to the young Bachchan when he began to learn to read. He recalled the opening lines, and also an alternative fourth line which the children always preferred:

Khaliqbari and CREATOR are the same,

Vahid is none but our GOD's own name;

As Rasul or Paigambar is the PROPHET known,

As Yar or as Dost may the FRIEND be shown.

Doggy drags him off by the ankle-bone. $!^{14}$

One aspect of my nervousness in awaiting Dr Bachchan's verdict on the translation concerned the title of the autobiography. None of the titles from the four Hindi volumes was appropriate for the consolidated version, so a new one had to be sought elsewhere. The half-line 'In the afternoon of time' in an autobiographical poem by R.L. Stevenson, is one in which the poet describes himself, in the

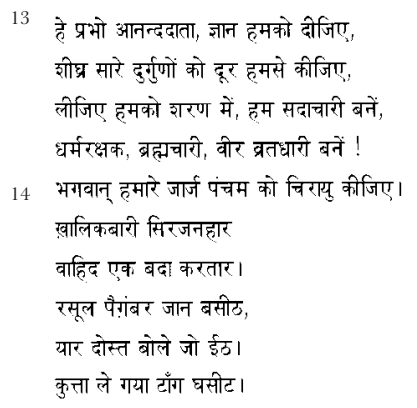


afternoon of his family history, as being the first member of the family to take to a writing career. ${ }^{15}$ Stevenson was a writer whom Bachchan himself had cited in his own work; and something of the romanticizing character of the quotation seemed of a piece with the Bachchan autobiography. Hearing the suggestion, Dr Bachchan thought for a moment, smiled, and said, 'Bahut acchā hai-I like it!' - a response whose bilingual wording seemed to vindicate the use of an English poet's words for the title of a Hindi work by an Indian scholar of English (and Hindi poet) in its English version by an English translator of Hindi. A further decision was that the translation should follow the usual English convention of being divided into chapters, unlike the original Hindi whose narrative was punctuated by nothing more than the occasional line-space at points throughout the four volumes. The narrative shape of the book suggested its own logical breaks as a basis for determining chapter boundaries, with chapter titles deriving straightforwardly from the content of the text.

The first difficulty in the actual process of translation was to find an appropriate English style to suggest the qualities of Bachchan's Hindi. His language draws freely on numerous complementary registers: the scholarly, with its high-flown Sanskritic vocabulary; the domestic, often tinged with the Awadhi colours of eastern U.P., especially in the speech of the author's mother; the humorous and punning, drawing on the rich resources of double-entendre which are so characteristic of Hindi style; the courtly, often reflecting the Urduspeaking Kāyasth heritage; the lyrical or sentimental, in which, as already noted, no barrier imposes itself between poetic and prosaic

15 'Say not of me that weakly I declined'

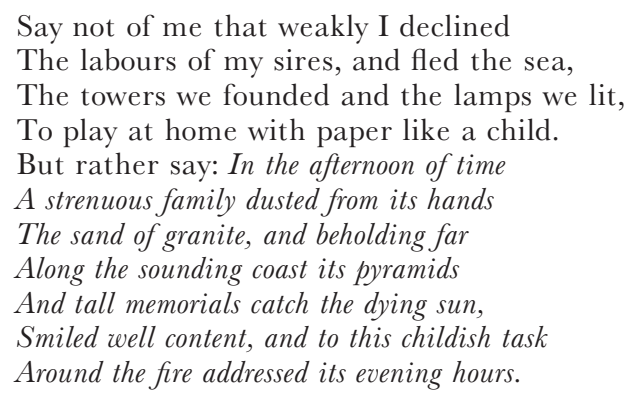

George Macbeth (ed.), The Penguin Book of Victorian Verse (Harmondsworth 1969), p. 328. (The italics are original.) See also the editor's biographical note on p. 327 . 
genres; and the lexically catholic register of down-to-earth everyday narrative.

What kind of voice should be adopted for the book? If authorial authenticity was the catchword, then the English of Bachchan's own Cambridge Ph.D. thesis, published by Motilal Banarsidass in India, might logically have provided a model; but then the universal garb of academic writing would look wholly out of place in the predominantly domestic context of Bachchan's intimately personal memoirs. What was needed was to create an idiomatic English voice, while not straying into stylistic territory which Bachchan himself would find unfamiliar; thus one had to forge a reproduction which would remain faithful to the flavour and spirit of the Hindi, while also being sufficiently readable to sustain the interest of an English readership. Some initial draft paragraphs revealed too closely the surface topography of the Hindi syntax; others strayed too far from the Indian cultural context, and seemed to invent a completely new text only distantly connected to the original-rather as though a plate of jalebis had been translated into a bowl of plum pudding. Revision of the drafts attempted to steer clear of both extremes, often finding that translation necessitated a change of imagery: a bhīgi billi or 'drenched cat' might become 'as timid as a mouse' without major damage to international understanding.

The easiest end of the spectrum was where Bachchan's Hindi itself showed the presence of underlying English syntactical patterns and cultural references. The clearest examples were in describing such English-medium events as a speech made by Dr P.E. Dastoor, a colleague of Bachchan's in the English department of Allahabad University. The urbane and sympathetic Dr Dastoor had aspired to the vacant Headship of the English department, only to be passed over in favour of Professor S.C. Deb. The university offered Dastoor an assistant professorship by way of consolation. Bachchan's narrative takes up the story:

A function was held in the department to celebrate this promotion. Dr Dastoor gave a brilliantly witty speech which I shall remember as long as I live. He said, "It is natural in this busy day and age that "Assistant Professor" should be abbreviated to "Ass Professor", and if anybody should appear to be ridiculed by such a designation I would blame the English language and not the user of the expression. I am very grateful that the administration has considered me worthy of the title "Ass Professor", but should like to point out that the real Ass Professor is Mr S.C. Deb, for it is he who will do the donkey-work of the department. The fact of the matter 
is that he will be an ass professor in deed and I will be an ass professor indeed'. ${ }^{16}$

The donkey is a safely universal figure whose perhaps slanderously negative stereotype translates readily enough between English and Hindi and back again; and a play in the last sentence of the English reflects the Hindi play ' $k \bar{a} m$ se... nām se'.

The linguistic context in the English department at Allahabad is again illustrated in Bachchan's portrait of its most Anglophile member, Mr Dayal:

Other contemporaries, albeit more recent appointees to the department, were Mr Bhagvat Dayal and Raghupati Sahay 'Firaq'. Mr Bhagvat Dayal had been educated in Anglo-Indian schools and in England-perhaps in Oxford-the full impact of which showed in both his pronunciation and his manner. When asked his name would say 'B. Dial'. [...] He was proud of being able to speak English like the English, and used to look down on people who spoke it with an Indian accent. We always shrank from talking to him because half of the English that emerged from his cigar- or pipeclamping lips was completely beyond us; if that was the case with us teachers, God alone knows what the students must have made of it. The only person able to speak on equal terms was Firaq Sahib: 'Mr Dayal, I'm beginning to understand your English again, I think it's time you made another trip to England'.

Such arch ironies indicate a depth of connection between Bachchan's text and the English-medium contexts being described in these passages. Unsurprisingly, then, there are occasions on which Bachchan's Hindi itself seems little more than a quick translation of an underlying English formula, as in the example 'I wanted justice, and fast' (maĩ nyāy cāhtā thāa, aur jald $\bar{a}, 2.248$ ). Similarly the expression viśvās mẽ lenā $\left(1.15^{\circ}\right)$ seems a transparent calque on the English 'to take into confidence', just as agar tum gambhīr the (1.200) can only mean, and derive from, the English 'if you were serious'. Likewise the use of the verb rahna for 'to live on, subsist on' in the clause vah

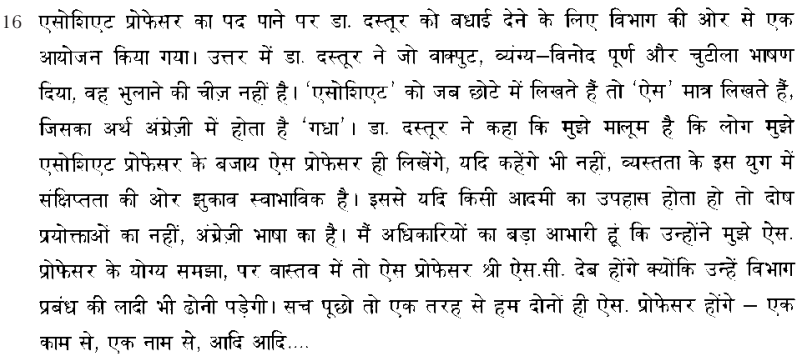


keval düdh-sābüdanna par rah rahı̄ thi 91.170) is in conflict with more usual expressions such as basar karnā or nirvāh karnā, while the sentence mã āndolan mẽ sakriya bhāg lene kĩ sthiti mẽ na thā begs to be restored to its underlying English 'I was in no position to take an active part in the movement'. In such usages we see Bachchan's Hindi usage quite deeply affected by his knowledge of the language which must have been second-nature to him after many years of teaching and studying, not to mention the English-speaking context of his various places of employment. Indeed there are occasions where Bachchan has resort to English words to fill out a sense not fully expressed by Hindi: un sebõ ke ek khās tarah ke svād, sugaṃdh ('flavour') ko mã̃ āj tak nah⿱一兀 bhūlā. Elsewhere, Bachchan's bilingualism contributes creatively to the Hindi lexicon, as when the alliterative compound tuk-tark nicely reflects the English original 'rhyme and reason'. Such usages as these make the process of translation one of re-translation, or rather of a restitution of the syntax, lexicon and idiom which underlies the Hindi expressions.

Given Bachchan's role as a translator of official documents for Nehru's foreign ministry, he had a professional interest in the appropriateness or otherwise of the neologisms that by common consent were necessary for the development of Hindi, and he often pauses in his narrative to ponder this or that turn of phrase. Seeking a translation for 'bona fides' he comes up with the nicely alliterative $n \bar{a} m-k \bar{a} m-d h \bar{a} m$, perhaps slightly at odds with the intention of the original but a convincing coinage none the less. Moments of hilarity in the neologism factories of the national language project were generated by such ridiculously ponderous proposals as vidyut prasāran yantra ('electrical broadcasting device') for radio, and the chestnut lauhpathgāmini ('ferrous-path voyager') for train; these were duly mocked by Bachchan's colleagues through waggish forays into the absurd, as in translating 'neck-tie' as kantha-langot ('larynx loincloth'). Another moment of comic relief is best told by Bachchan himself:

I recall another incident when the sub-committee on non-scientific vocabulary, chaired by the poet Dinkar, was discussing the translation of the term 'Customs House Officer'. 'Customs' was rendered sima shulka; 'Customs House' became sima shulka sadan; and 'Customs House Officer' sima shulka sadan adhikari-at which Dinkar exclaimed 'It's a perfect Tulsidas chaupai line!'

A number of English idioms arising in Bachchan's Hindi text are slightly at odds with contemporary usage, or reflect half-remembered aspects of British life. Examples are his slightly wayward use of the 
idioms 'dark horse', 'pent up', 'rough it', the wholly logical but nonetheless deviant expression 'lecturership', and some wrongly remembered values for English currency. Such minor infelicities, together with several small mistakes in the quoting of English verse, were best silently corrected in the translation. The preponderence of rhetorical questions (what could be more typical of Hindi prose style?) was also necessarily reduced in the translation.

Conversely, many aspects of Hindi idiom present real difficulties to the translator. Particular ways in which a slight modulation of word order or emphasis lend a certain shade of meaning to the Hindi sentence seem clumsy or self-conscious in their English dress. Those notoriously untranslatable emphatic particles $h \bar{\imath}$ and to tempt the translator to rely too heavily on the much less subtle resources of words such as 'itself' and 'indeed', which invariably bring a clumsiness to the English phrase; worse, they tend to transform a contemporary idiom into a kind of neo-Victorianese. The difficulty is to break out of the straitjacket of the source language and to produce a version which makes sense in the idiom and style of the target language.

Innocent-seeming words or phrases can prove surprisingly difficult to render convincingly in English. Even such an apparently simple item as the verb sunāna has no wholly adequate English equivalent: the closest, 'to recite', has too formal a connotation when the context is spontaneous and domestic. A word frequently encountered in the prose of Hindi writers is buddhijivi $\bar{l}$, generally rendered by the word 'intellectual'. It may be that take-up and usage of the Hindi word has itself been influenced by the existence of its English equivalent; but whereas buddhijīvi sits well enough in the context of a Hindi sentence the English equivalent has a pretentious ring, making 'professional' sometimes seem a preferable substitute.

Finding acceptable equivalents for words and phrases is hard enough within a single context of usage; but when the author makes a word do double duty in two distinctive but linked contexts, the problem is exacerbated. An example is in a passage where the recently bereaved Bachchan describes an incident with his college friend, the Hindi poet Shamsher Bahadur Singh.

I remember walking down the stairs with him one day after class, where I had been thinking that my own grief was a barrier which alienated me from my classfellows, preventing me from establishing a closeness with any of 
them. Some lines of Mahadevi's came to mind and I recited them to Shamsher:

Within the ample dome of arching sky would I, a shred of water-weeping cloud no merest corner of my own enshroud. Here's my life's report and history:

Prevailing briefly, I'm to drift and vanish by and by. ${ }^{17}$

I had thought the lines would cast Shamsher into a sober mood; but to my astonishment he turned from the step below me with a laugh, jumped back up beside me, took my right hand in his left, threw his head back, shot his right arm up in the air and declared,

By and by we drifted, tomorrow we prevail! ${ }^{18}$

The fifth line of Mahādevī's quoted verse reads umaṛi kal thī, mit $\bar{a} j$ cali. The verb umarna lacks a satisfactory synonym in English, and Shamsher's reworking of this final line ('mit a j cale, umarẽge kal!') requires the verb to work within both past- and present-tense contexts-both umarī kal thī, and umarẹge kal. 'Prevail' is a compromise solution, accommodating both contexts but admittedly ideal in neither. The delightfully ambivalent chronology of the adverb $\mathrm{kal}$ ('yesterday/tomorrow') is a further problem, addressed if not solved with 'by and by', whose weak rhyme with 'sky' and 'history' reflects that of cali with badali and yahi.

Bachchan's use of English vocabulary embedded within Hindi sentences sometimes invites comment. In a moving passage describing his father's uncharacteristic acquiescence to Bachchan's liaison with a Christian girl called Iris, Bachchan uses the English word 'efface' in the sentence 'Father had already denied his own personality for the sake of mine: that night, he seemed to efface himself utterly'. The code-switching has a particularly contrastive effect: it leans out from the base language to reach a loanword whose 'otherness' within the sentence emphasizes the peculiar deviance of the situation being described. The contrast is lost when the whole sentence is rendered in English; neither italicization nor inverted commas would sufficiently mark the verb. A similar crux appears a few pages later, when Bachchan expresses the difficulty in expressing in Hindi the idea of

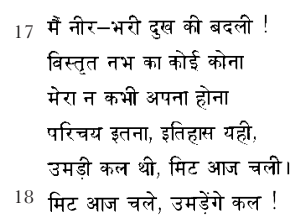


'cynicism', which he wishes to invoke in describing the mood in which he wrote a particular poem.

In the translation of idiom and playful language there is an unavoidable loss, either of sense or of sensibility. A typical problematic passage is that in which Bachchan describes amateur dramatics rehearsals beset by truancy among the actors: some have 'zarūri $k \bar{a} m$ ', others 'zarūri ārām'. To lose the playful sarcasm of this parallelism is to condemn the passage to blandness; so rather than slavishly following the exact wording of the Hindi idiom it seems better to invent a parallel word-play in English, with 'urgently working-or urgently shirking'.

Maintaining in the target language specific contrastive registers in the source language is perhaps impossibly difficult. An example is in Bachchan's description of his encounter with two well-known personalities from Indian public life: Maulana Azad and Rajendra Prasad. Bachchan's search for a grant to fund his longed-for visit to England and Cambridge had brought him to the seat of power in Delhi, where he first sought an audience with Azad, the Education Minister in Nehru's government; Azad's language strains at the limits of the definition of Hindi, and begs to be called Urdu-a reminder, perhaps, not only of Maulana Azad's own cultural background but also of Bachchan's own Kāyasth heritage. Later in the same page, Bachchan relates his visit to an even higher authority, the President of India, and the language shifts dramatically to a fluent Sanskritized register wholly of a piece with Dr Rajendra Prasad's own cultural world. ${ }^{19}$

Another area of loss in translating Hindi narrative prose is the specific flavour of dialect in conversation. Much of the special Awadhi register of Bachchan's neighbourhood has had to be foregone in English: there seems no workable way of substituting a convincing rustic register without going over the border into parody or pastiche-Premchand's Godān relocated in Hardy's Wessex. Ian Raeside has written about this problem in respect of Marathi fiction; ${ }^{20}$ and Gillian Wright has more recently encountered it in her brave but

\footnotetext{
19 Maulana Azad is characterized by the phrase 'तहुजीब व तमद्दुन व तालीम के गढ़े-छीले मुतकल्लिम (बोलते ह्राए) पुतले', and Rajendra Prasad by the phrase 'शिश्चचार और विनम्रता की मूर्ति' (H.R. Bachchan, Basere se dür (5 th edn, Delhi, 1989), p. $3^{6}$ ).

${ }^{20}$ Ian Raeside, 'Translating the untranslatable: some problems in the translation from Marathi of dialect prose and lyric verse', in Alokeranjan Dasgupta (ed.), Problems of Translation from South Asian Languages (Heidelberg, 1978, South Asian Digest of Regional Writing, vol. 7), pp. 35-6o.
} 
ultimately unsuccessful attempt to make some of Shrilal Shukla's Awadh villagers in the novel Rāg Darbāri lapse into a bizarre idiolect sometimes suggestive of a 'trouble at mill' Yorkshire. ${ }^{21}$ Bachchan's text compounds the problem with punning language in a passage that borders on the surreal: two local characters, Issar the carter and his spirited wife Jugni, dance the night away in a competitive test of vigour and personal honour. In the midst of this manic dancing Jugni sings the line sajan kĩ hāt maĩ to jobanā luțāy dihẽv, 'I spent my youth in my lover's market', which Issar later twists into the form sajan ke häth maĩ to jo banā luțāy dihẽv, 'I spent whatever arose in the hand of my lover', changing hät 'market' to häth 'hand' and jobanā 'youthfulness' into jo bana 'that which was made'. The dialectal voice eludes translation, but the substitution can be suggested by the contrastive versions 'In the mart of my loved one, I spent my soul tender', versus 'For the heart of my loved one, I spent my sole tender'-always hoping that the sympathetic reader would accept the transformation of the word 'tender' from adjective to noun.

Quite apart from the long spell in England and Ireland described in the third volume of the autobiography, many of its most plangent moments make reference to English literature or to the culture from which it springs. There can be no finer example than the very moving description of the illness and death of Bachchan's one-time boss, Jawaharlal Nehru; the well-known story of Nehru's last days is told here in the words of a close colleague. By chance, this passage also affords a glimpse of Bachchan's skills as a translator in his own right, for it includes his sublime Hindi version of those famous lines of Robert Frost's poem 'Stopping by Woods on a Snowy Evening' that were found lying on Nehru's desk at his death. This verse is almost as well-established a part of the enduring Nehruvian image as the lapel rose or the 'tryst with destiny' speech of August $1947 .{ }^{22}$ Here is the passage, first in English with Frost's original lines, and then Bachchan's Hindi rendering of the verse.

As soon as his health improved a little [Nehru] began to work againprobably too much, as though he had a sense that his time was running out.

${ }^{21}$ Shrilal Shukla, Raag Darbari, trans. Gillian Wright (Delhi, 1992). See, for example, p. 23: 'Bhaiya, if tha' goest on like this tha' canst forget Vice Principal.'

${ }^{22}$ Its 'miles to go before I sleep' phrasing, and the repeat of that famous line, have even become the subject of allusive intertextuality or parody in the following passage from a novel by Rukun Advani: 'I was happily operating, left, right and centre, frontways and sideways, for gall stones, kidney stones, gall stones, kidney stones. There were miles of stones to go before I slept. And you can say that again.' Rukun Advani, Beethoven Among the Cows (Delhi, 1994), p. $15^{\text {o. }}$ 
On 26 May before retiring for the night he said to his personal secretary, 'I think I have dealt with everything'. And the sleep he took on the next morning was his last. On a paper lying on his desk he had written the lines of Robert Frost:

The woods are lovely, dark, and deep,

But I have promises to keep,

And miles to go before I sleep,

And miles to go before I sleep.

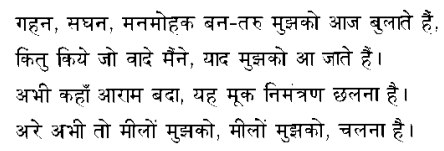

These four lines of verse constitute an entire course in the art and craft of translation. The Hindi poem is not a dead replica of its English model but a living expression of the feelings engendered by reading the original; it is respectful to the wording and structure of the English without being bound to it hand and foot. The Hindi refashions Frost by assimilating it to an Indian landscape; his American woods, 'lovely, dark and deep', are represented in Hindi by the ban-taru, whose qualifications as gahan, saghan, man-mohak, suggest a grove on the Jumna bank, a secluded Gĩtagovinda arbour. No less characteristically Indian is the use of a rhetorical question in the

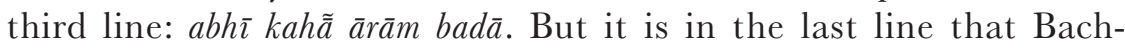
chan's skill shows most clearly: rather than dutifully reproducing the whole-line repeat of Frost's original 'and miles to go before I sleep', he picks out just a few syllables-the alliterative collocation mîlo mujhko-and achieves the climax of the poem in the repeat of these alone.

Elsewhere there are other examples of Bachchan's inventiveness in Hindi that can only be silently admired by the translator: words such as the sublimely intercultural abstract noun narvasta $\bar{a}$ 'nervousness' (IV. 122), or the elegant compounds navambarānt 'the end of November' (IV. 138), and fonādeś, awkwardly to be translated as 'telephone instruction' (IV. 164). The expression kamān karnā 'to command' (in the context of a university training corps) not only delivers a clear meaning through a widely understandable English loanword (lightly Indianized by dropping the final $-d$ ), but also manages to suggest a military context through association with the Hindi word meaning 'bow'.

This survey of translation issues may be concluded with a final example which allows a reiteration of some of the main points. The 
passage occurs when the young Bachchan, seeking answers to the perplexities of life after a bereavement, crept into his father's pujaroom to read the Gītā.

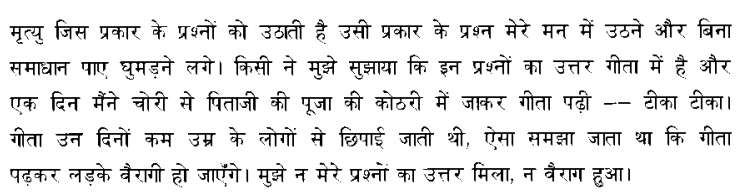

In this passage the hand of English usage is again plainly to be seen: the phrase praśna uṭhānā, for example, is surely nothing more or less than a Hindi rendering of the English 'to raise a question'. But the passage also reflects the different genius of the Hindi language. Perhaps its most significant feature lies in the verb ghumarnā, strongly suggestive of the massing dark clouds of a monsoon sky; to translate this merely as 'to gather', dropping the meteorological reference, would be to emasculate the imagery. Then there is the question of how adequately to capture the sense of vairägya, so much more a part of an Indian world-view than an English one. More conveniently, the surreptitiousness of the Hindi adverb cori se 'by stealth' has a closely literal parallel in English. These various issues can be addressed as follows:

All the questions that death raises rose up in my mind and massed there like gathering clouds, unresolved. Someone suggested to me that the answer to these questions was to be found in the Gita, and I stole into Father's puja room and read it, following the commentary. In those days the Gita was hidden from young people, lest it encourage them to turn away from the world; but I neither found the answers to my questions, nor relinquished worldliness.

The many continuities and discontinuities that characterize the relationship between Hindi and English in this text, and mutatis mutandis in its translation, raise interesting questions as to the likely readership for literature of this kind. A standard argument for translation, that it brings the original to a wider readership, is made by one of the characters in the autobiography itself. Bachchan writes:

Vansho ${ }^{23}$ also translated my poetry into English, and tried to show that the translation was much stronger and more beautiful than the original. Per-

23 'Vansho': Raghuvansh Kishore Kapoor, a professor of English at the Hindu Sabha College, Amritsar. 
haps others felt so too: English was the language of our rulers and anything uttered in it seemed to bear more gravitas. He maintained that if I only wrote in Hindi the outside world would never hear of me, while his translations could establish me internationally.

In the context of Hindi, however, the 'international' character of a likely readership includes many Hindi-speakers for whom the prospect of reading a book in Hindi would be quite unthinkable; ${ }^{24}$ note the clear demarcation between Hindi and English bookshops in Delhi or Bombay. Younger members of the Bachchan family, reading the draft of my translation without having encountered the original, came to know for the first time that their grandfather had been married twice. Thus English, 'India's auntie-tongue' in Probal Dasgupta's improbable phrase, ${ }^{25}$ has displaced Hindi as literary vehicle for a large self-defining elite, just as surely as the Maruti saloon has replaced the Ambassador, which in turn had replaced the tonga. The implications of this general tendency, often observed in Bachchan's autobiography and variously opposed and exacerbated by the respective parts of his career, mean that in this example the purpose of translation from Hindi may be to make the author better known in his own land, rather than necessarily 'internationally'.

The network of social, political and cultural factors underlying this situation is vastly more complex than any simplistic explanation would allow. But one aspect of the situation, the matter of readership, is closely relevant to our present discussion. Introducing her translation of Shrilal Shukla's novel, Gillian Wright comments on the linguistic caste system which so radically distinguishes the world of English from that of Hindi across the tracks: 'Raag Darbari is not widely read in Delhi society and you'd be hard-pressed to find anyone who'd heard of it or its author at the average dinner party. The latest English novels, on the other hand, are a favourite subject for discussion. ${ }^{26}$ Thus far, the point is well made (even if the definition of 'the average dinner party' begs the question rather egregiously: Hindi speakers too may live in Delhi, doubtless eating dinner while doing so). But the statement that follows is more contentious: 'But no novel I have read in English comes close to capturing life in an

\footnotetext{
${ }^{24}$ An Indian writer of English, speaking about the status of Hindi in Delhi in a recent discussion at the Nehru Centre in London, referred to Hindi as the language of 'taxi-drivers, waiters and things'.

${ }^{25}$ Probal Dasgupta, The Otherness of English: India's Auntie-tongue Syndrome (New Delhi, 1993) .

${ }^{26}$ Shrilal Shukla, Raag Darbari, p. v.
} 
ordinary north Indian village, whereas the smell of the earth of Uttar Pradesh emanates from every page of Raag Darbari.'

Such an opinion, while motivated by a sincere desire to achieve greater exposure for the Hindi novel, plays into the hands of a toofrequent representation of Hindi literature as a source of mere narrative ethnography. It represents Hindi writing as a country cousin of urbane, universal English, and condemns it to a role as provider of local colour. Commenting on Wright's statement, Harish Trivedi notes laconically, 'This is all true enough, but are there readers anywhere in the wide world, even beyond the irredeemably deracinated circle of dinnerparty goers in New Delhi, who would care to smell the earth of Uttar Pradesh?'27 A resounding 'no' has famously been given to this rhetorical question by Salman Rushdie in his recent ex cathedra pronouncement on the literature of "the so-called "vernacular languages" - a dictum which has rapidly taken its place alongside Macaulay's Minute in the rogues' gallery of cultural judgements:

$[\mathrm{T}]$ he prose writing-both fiction and non-fiction-created in this period [1947-97] by Indian writers working in English, is proving to be a stronger and more important body of work than most of what has been produced in the 16 'official languages' of India, the so-called 'vernacular languages', during the same time. ${ }^{28}$

While Indian commentators have legitimately taken Rushdie to task for what they see as an uninformed and partisan attack on Indian literatures in languages other than English, one important aspect of his (doubtless carefully-worded) statement seems not to have attracted much comment. Rushdie speaks here of a 'body of work', taking care to stress 'both fiction and non-fiction'; and it is true that for a reader such as Rushdie whose access to such literature is only through translation, the choice of available prose titles beyond the fiction list is indeed a very small one. Though such a recommendation is admittedly self-serving in the present context, the claims of non-fictional genres also deserve attention if the wealth and breadth of literature in a language such as Hindi is to achieve any just recognition beyond its own hinterland.

The linguistic awareness of Bachchan, Hindi poet and English teacher, suggests that his autobiography has much to offer to both

\footnotetext{
${ }^{27}$ Harish Trivedi, 'The politics of post-colonial translation', in Avadesh K. Singh, Translation: its Theory and Practice (Delhi, 1996), pp. 53-4.

${ }^{28}$ Salman Rushdie, introduction to The Vintage Book of Indian Writing 1947-1997, ed. Salman Rushdie and Elizabeth West (London, 1997), p. x. Italics original.
} 
Hindīvālās and Anglophiles; it is a particularly rich source for readers interested in the polyphonic interplay between the rival languages. Bachchan's many asides on linguistic contexts run through every chapter of the work, whether it be an observation on the universal applicability of Tulsīdās, the discovery on arriving in London that the plural of the slang for the English shilling is 'bob' not 'bobs', or the realization that the setting up of a Hindi unit within the Foreign Ministry of the Indian government was actually nothing less than a cynical subterfuge to prevent anyone else ever having to take Hindi seriously. 